\begin{tabular}{|c|c|c|}
\hline 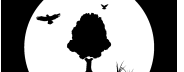 & Our Nature & $\begin{array}{l}\text { ISSN: 1991-2951 (Print) } \\
\text { ISSN: 2091-2781 (Online) }\end{array}$ \\
\hline $\begin{array}{l}\text { Vature Conservation \& } \\
\text { Healith Carre Council } \\
\text { Biratinagar Nepal }\end{array}$ & Journal homepage: http://nepjol.info/index.php/ON & (c) \\
\hline
\end{tabular}

\title{
Traditional honey harvesting by the Pnar community of South Assam, India
}

\author{
Biswajyoti Bikomiya Deori ${ }^{1}$, Panna Deb ${ }^{1,2^{*}}$, Hilloljyoti Singha ${ }^{1,2}$ and Manabendra Ray \\ Choudhury ${ }^{1}$ \\ ${ }^{1}$ Department of Ecology and Environmental Science, Assam University, Silchar-788011, Assam, India \\ ${ }^{2}$ Centre for Biodiversity and Natural Resource Conservation, Assam University, Sichar-788011, Assam, India \\ *E-mail: pannadeb@rediffmail.com
}

\begin{abstract}
Honey obtained from the bee hives is a sweet food and has a great medicinal value. Honey collected from nature by the ethnic communities is an important source of nutrition and also contribute to their income generation. Honey collection from the wild is especially done by the indigenous tribe and forest dwellers. The Pnar community living in Barak Valley, South Assam is also engaged in the collection of honey from the forest, especially during the spring season. The process starts with the gathering of information, followed by the preparation for the activity and subsequently extraction of honey from the bee hive. The technique used by the Pnar community is a challenging one as it involves harvesting of honey from lofty trees in forest with traditionally made gears like bamboo basket, smoke torch and a one bamboo ladder. The indigenous ways involves lining the bamboo basket with leaves for the collection of honey, using smoke to frighten the bee and storage of honey in the bamboo pipes. The present study exhibits the rich traditional knowledge that has paved the way for a sustainable livelihood since long and at the same time provides income generation opportunity for the community.
\end{abstract}

Key words : Barak Valley, Bee, Ethnic community, Traditional knowledge

DOI: http://dx.doi.org/10.3126/on.v14i1.16436

Manuscript details: Received: 27.05.2016/ Accepted: 19.08.2016

Citation: Deori, B.B., P. Deb, H. Singha and M.R. Choudhury 2016. Traditional honey harvesting by the Pnar community of South Assam, India. Our Nature 14(1):13-21. DOI: http://dx.doi.org/10.3126/on.v14i1.16436

Copyright: (C) Deori et al. 2016. Creative Commons Attribution-NonCommercial 4.0 International License.

\section{Introduction}

Traditional knowledge (TK) is the wisdom that is passed on from one generation to another and it includes the sustainable use of natural resources from its surroundings (Raut et al., 2012). With changing socio- 
economic conditions, now these wisdoms are getting eroded day by day. All over the world there has been an increasing realization among the scientific community about the human-nature interaction (Upadhaya et al., 2016). World health organization estimated that almost $80 \%$ of world's population are still dependent upon the traditional usage of natural resources for health care (Upadhaya et al., 2016). An estimated 50 million economically marginalized forest dwellers in India harvest large quantities of NTFPs for their subsistence as well as for trade. Non-timber forest products (NTFPs) are the materials from both plant or animal origin, which is derived from the forest and allied land uses for daily use as well as for income generation (Dattagupta et al., 2014).

Honey is a delicacy which also has substantial medicinal properties; thus, it has a great demand throughout the year especially for its Ayurvedic medical utilities (Demps et al., 2012). In India, honey is obtained mainly from Apis dorsata, A. florea, A. cerana, and A. mellifera. Among these, A. cerana and A. mellifera are cultivated by the people for honey production, while $A$. dorsata is a wild rock bee and has still not been domesticated. The collection of honey from the forested landscape is prevalent mostly among the tribal communities and forest dwellers viz. Jenu Kuruba of Karnataka, Kurumbas and the Irulas of Nilgiris and the Mowals, an indigenous community of Sundarban (Demps et al., 2012).

Pnar or Jaintia community are the subpopulations of Khasi tribes. They are of mongoloid race and speak Mon-Khmer dialect of an Austric language (Tyagi, 2000). Pnar are mostly concentrated in the Jaintia Hills of Meghalaya with a scattered population in surrounding foothill regions of $\mathrm{Ca}$ - char, Karimganj and Hailakandi district of Assam (Tyagi, 2000; Dattagupta et al., 2010; Nath et al., 2011; Dattagupta and Gupta, 2014). They are mainly agriculturist and known best for their betel leaf cultivation or paan jhum cultivation in the area (Tyagi, 2000; Dattagupta et al., 2010). They possess high indigenous knowledge system in the utilization of the rich plant diversity around them for their daily needs (Samati and Begum, 2006). The Pnar people mainly engage themselves working in the Paan jhum fields throughout the year and also collect minor forest products and wild edible fruits like bamboo, mushroom, firewood and honey from the surrounding forest. Though the collection of honey from the wild is a challenging task, the Pnar people with their indigenous ways collect honey efficiently. In this paper, we have documented the traditional techniques opted by the Pnar communities for the collection of honey from the forest.

\section{Methods \\ Study area}

The present study has been carried out in the villages of Marwacherra Part I and II (N24 $58^{\prime} 619^{\prime \prime}$ E92 $566^{\prime} 837 ", 30$ m asl); Bombaithol $\left(25^{\circ} 03^{\prime} 589^{\prime \prime} \mathrm{N} \quad 092^{\circ} 38^{\prime} 005^{\prime \prime} \mathrm{E}\right.$, $49 \mathrm{~m}$ asl $)$; Kayang $\left(25^{\circ} 05^{\prime} 101^{\prime \prime} \mathrm{N}\right.$ 92 47'47.6"E, $109 \mathrm{~m}$ asl); Nuncheeri (2501'705"N 092 42'395"E, $365 \mathrm{~m}$ asl); Durbintilla $\left(24^{\circ} 01^{\prime} 47.4^{\prime \prime} \mathrm{N} \quad 92^{\circ} 46^{\prime} 32.9^{\prime \prime} \mathrm{E}\right.$, $309 \mathrm{~m}$ asl); Kochukhal $\left(25^{\circ} 02^{\prime} 551^{\prime \prime} \mathrm{N}\right.$ $092^{\circ} 41^{\prime 201 " \mathrm{E},} 332 \mathrm{~m}$ asl); Indranagar (24 59'12.9"N 092 51'55.4"E, $49 \mathrm{~m}$ asl) and Durgacherra $\left(25^{\circ} 01^{\prime} 13.7^{\prime \prime} \mathrm{N}\right.$ 92 46'26.9"E, $109 \mathrm{~m}$ asl) located near the Barail Wildlife Sanctuary (BWLS), Cachar district in South Assam (Fig. 1). The BWLS is situated in the northern part of the Cachar district of Assam and lies along the 
foot hills of Barail Hill Range. The villages investigated are inhabited by the Pnar community. The field observations were made from December 2013 to March 2015. The forest types of the study area can be broadly classified under 1BC3 Cachar Tropical Wet Evergreen and 2BC2 Cachar Tropical Semi-Evergreen forests (Champion and Seth, 1968). The area has a typical subtropical monsoon climate (Anonymous, 2011).

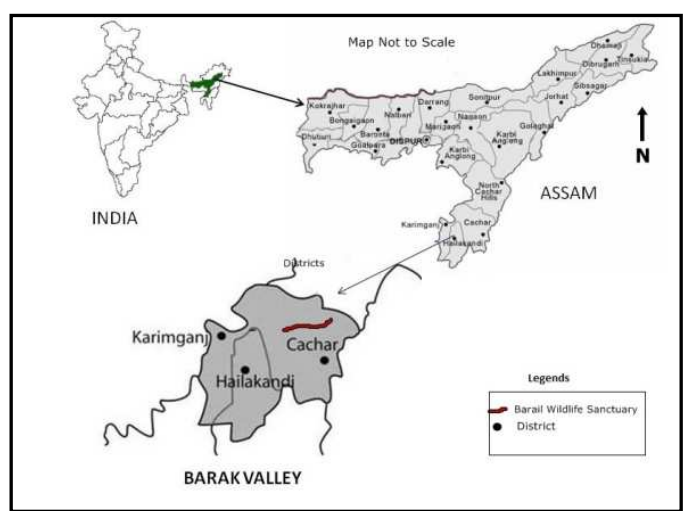

Figure1. Map of the study area.

\section{Data collection}

Primary data were collected through the household survey, focused group discussion, personal observation and participatory rural appraisal (Cotton, 1996). We tried to document the technique and procedures opted for the collection of honey from the forest. Field visits were made during honey collection with the local people. The plants used in the collection of honey were collected and later identified by consulting herbaria of Botanical Survey of India, Eastern Circle, Shillong, Meghalaya. The honey bees were identified by consulting with experts from Assam Agriculture University, Jorhat, Assam. The headman and the people interviewed were appraised about the purpose of the study.

\section{Results and discussion Honey bee types}

Pnar people call the honey bee as Umngap. We found four types of honey bees to be occurring in the study area. Depending upon the habitat and size of honey bee, the Pnar people categorised them into four main types:

i. Ngap-Kwep (Small bee, Apis florae): These are wild in nature and choose shaded place among bushes and trees for making their hive. The quantity of honey yield is very little ranging about 200-250g per colony (Rahman and Deka, 2008).

ii. Ngap-lawe (Large bee, Rock bee, Apis dorsata): This species is larger in size than all other bee species. It builds a single comb fix to a tree branch or under the roof of rock. Bees cover the comb like a curtain and a colony can yield upto $50 \mathrm{~kg}$ of honey. The bee migrates long distances from plains to hills to avoid dry dearth period and unfavourable weather condition (Rahman and Deka, 2008).

iii. Ngap-rapiang (Medium size, Indian bee, Apis cerana): It is a domesticated variety of honey bee and available throughout the continent. There are different races of Apis cerana found in India. Apis ceranahimalaya, a medium sized honey bee is found in the Northeastern region of the country. It makes hive under the tree hole, rock hole and even under the ground. The honey yield varies from 12 to 15 kg/hive/annum (Rahman and Deka, 2008).

iv. Ngaosnon (Medium size, Western bee, Apis mellifera): This species of bee is most widely distributed and commercially reared honeybee species in the 
world. The average honey production from this species is between $30-40$ $\mathrm{kg} /$ hive/annum (Rahman and Deka, 2008).

\section{Techniques of honey extraction}

Honey collection is a challenging task as there is a risk of attacks by the bee. Honey collection technique has been passed down from one generation to another. They have been following the age old tradition even in the absence of written records and formal instruction. The present paper describes the technique of honey collection from the hives of Apis dorsata (Ngap-lawe). The Pnar community mainly collects the honey during the month of March-May (spring season) each year. The process of the honey collection begins with the gathering of information followed by time fixation for extraction, making arrangements for the required tools and utensils and finally cutting the bee hive and filtration. The process is discussed in detail below:

Gathering information: They usually gather information about the beehive during their work in the betel leaf cultivation field. Whenever they encounter bees flying nearby they focus on a particular bee and follow its trail. Once the hive is located and identified, they fix the plan for honey collection based on size, position, and location of the hive. The honey bee usually selects the big trees with profuse branching and spreading crown such as Mangifera sylvatica L., Artocarpus chaplasha Roxb, Spondias pinnata (L.f.) Kurz, Chrysophyllum roxburg- hii G.Don, Pterospermum acerifolium (L.) Willd etc.

Fixing time to extract the honey: There is usually no fixed time for honey collection, but there is a general belief that during the full moon, it produces more honey as compared to the other time. Depending upon the location, the size of the hive and height at which the hive is present in the tree, they fix a time to cut the comb. They mostly collect honey during the daytime, but sometimes,collection is done during the night also when the hive is located very high in the tree or in some precarious positions. Usually, honey is collected individually but in case of bigger hives, two to four persons are involved.

Tools required for honey collection: The Pnar people mainly use the knife (Waip) in the honey collection. Though, there is no special knife for cutting the comb, but when the hive is in the tree hole, they use a special kind of knife called Waip-erdet (Waip means knife and er-det under the hole) (Fig. 2A). For collecting honey from the tree they use a bamboo basket called khara (Figs. 2B-C). The size of the khara is around 1.5 feet.They also use a special kind of ladder Jinkein made of single bamboo (Fig. 2D) to climb tall trees without branches. The Jinkein is very characteristic to the collection of honey from very tall and robust trees with less branching.

Procedure for cutting the comb: They use smoke and chase technique for cutting the comb. The group members distribute the work among themselves. They first prepare 


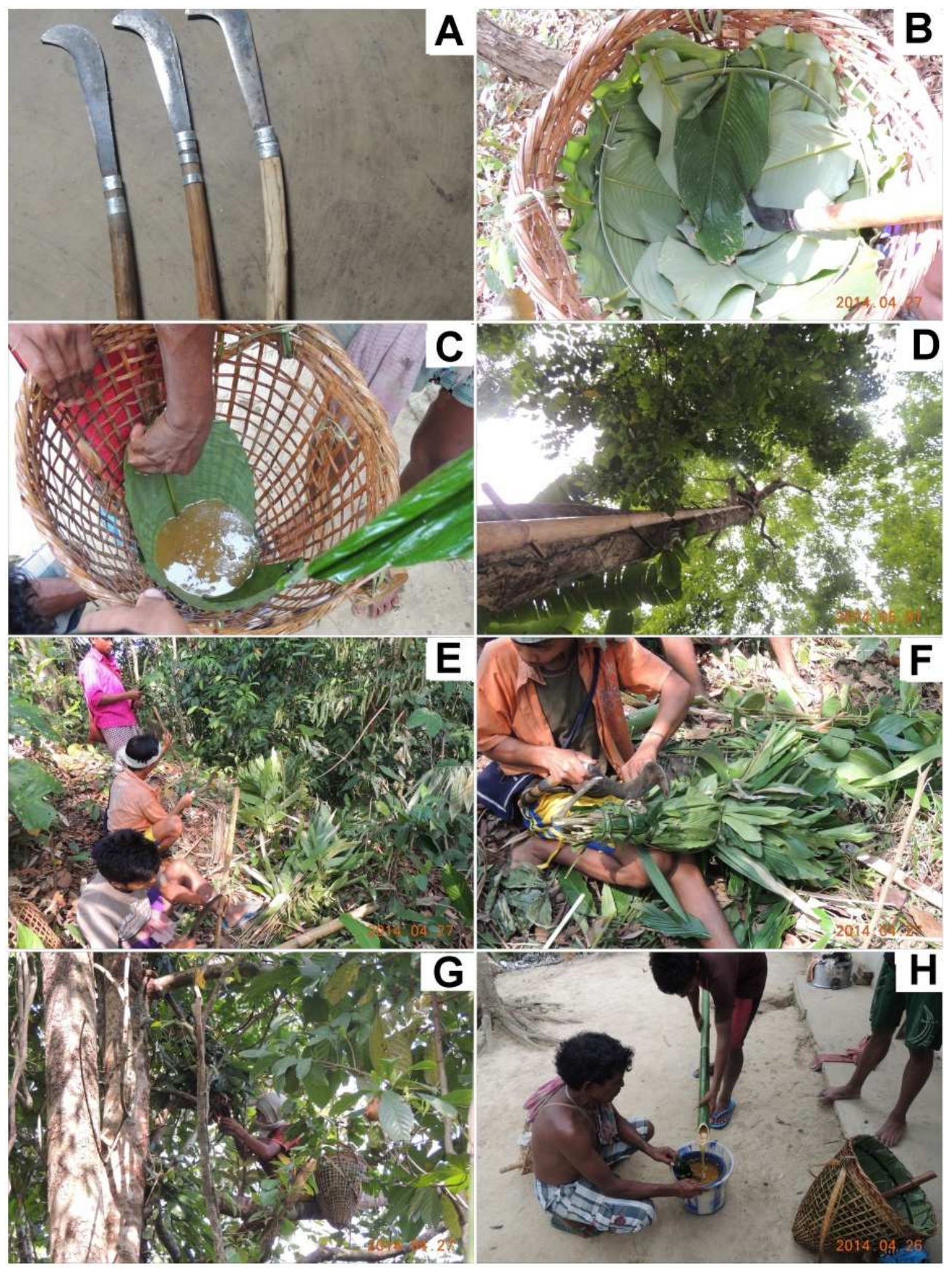

Figure 2. Honey collection procedure by Pnar community: A) Knife used during honey collection, B) Khara lined with Phrynium leaves, C) honey collected in a Khara, D) Jinkein used for climbing trees, E) Preparation of smoke torch, F) preparation of torch using Alpinia leaves, G) Man climbing tree with smoke torch, H) Filtration of honey. 
a bamboo torch with dry and fresh leaves of Latar (Phrynium punenurve (Gaertn.) Burtt to produce smoke (Figs. 2E-F).They then arrange the Phrynium leaves (Sla-la-met) in the khara to collect the honey. They place Phrynium leaves inside the Khara in such a manner that the honey does not come out of it (Fig. 2C).

The person carrying the bamboo torch always covers his face with a piece of cloth and hold the smoking torch while cutting the comb in order to escape from being stung by the bees (Fig. 2G). With the fumes of the torch, the honey bees generally flee away leaving the hive. The bee hives are collected during that period very fast. They will leave some portion of the hive on the tree so that the bee can again rebuild its hive. As soon as the comb is cut, the collected hives are immediately placed in the basket (Khara). The persons collecting the honey will be carrying the bamboo torch for some time even after climbing down from tree to protect himself from the attack of furious bees who had been displaced from their hives. In the event of being stung by the bees, honey is immediately applied in the affected area to get relief from the pain.

Filtration and preservation: The freshly collected honey is a mixture of wax and sometimes the young bee from the hive are also found. They would then filter the impure honey for preservation. They filter it with a sieve made from bamboo and preserve the honey in a bamboo or a glass jar (Fig. 2H). After filtration, if the wax is left in high amount, they use it to prepare candle.

Tropical forests provide a large number of products such as fruit, seed, resin, medicine, wildlife meat and by-products defined as non-timber forest products (NTFPs). NTFP extraction can contribute positively to sustainable forest management as it provides tangible economic benefits to poor rural communities whilst simultaneously conserving biodiversity (Peters, 1989; Kaushal and Melkani, 2005; Mahapatra et $a l .$, 2005). Since very early times the traditional societies have a sound traditional knowledge which can be attributed to their rich experience and close interaction with the natural ecosystem. The knowledge is neatly woven into their culture and has percolated from one generation to another and played a significant role in shaping their cultural identity. The traditional communities have always depended on natural resources and have always been sustainable in their approach to handle it. Honey collection by the Pnar community of Barak Valley, located in the southern part of Assam provides a similar case of sustainable use of forest resources in the area. Though they collect the honey for personal consumption, yet the surplus is often sold and is a good source of income generation. Honey has tremendous socio-economic value in terms of its use in rituals, social, and health benefits. The market price of honey varies from Rs. 300-400 per litre in the local markets. Honey collection is one of the favourite hobbies and earning source for the community. The knowledge pertaining to honey collection signifies the rich traditional knowledge of the ethnic community.

The honey collection from wild has been a traditional practice maintained by different tribes and communities in India and neighbouring countries (Zvelebil, 1979; Demps et al., 2012; Sohela, 2013; Singh, 2014). A study in Nagaland reveals that among the 150 bee keepers, $86 \%$ have learnt the process of honey harvesting tradi- 
tionally (Singh, 2014). In the Nilgiri hills, gathering honey from the wild has been the regular occupation of the Kurumbas and the Irulas tribes (Zvelebil, 1979). Honey collecting has been and still is an important economic and ritualistic activity for the Jenu Kuruba tribe in Karnataka, India. The practice is so popular that the tribe is named after Jenu which means honey in the local dialect (Demps et al., 2012). Like Jenu Kuruba in India, Mowals, one of the indigenous communities of Sundarban, Bangladesh is engaged in the honey collection (Sohela, 2013).

The 'smoke and chase' technique is a common practice in the subcontinent; however, there are differences in application depending on the local conditions and availability of natural resources. In Nagaland, India, the honey collector would eat garlic, ginger and other edible fruits from the forest and blow the hive to tame the bees (Singh, 2014). In most of the cases, the main collector carries the torch to smoke, but Kurumbas adopt a different technique; a person smokes below the hive, while the main collector descends down from steep rock by a ladder made up of wild creeper (Zvelebil, 1979). In Nilgiris, they collect honey from bee hive hanging on huge rocks; hence, they use a rope ladder to swing to reach the hive. In Sundarban, Bangladesh, the leader climbs up the tree to reach the beehive, while another person holds the long stick to make smoke from the ground (Sohela, 2013). However, in the case of Pnar community of Barak valley, Assam, the honey collector himself climbs the tree with a bamboo torch to smoke and cut the comb. He does almost the entire process by himself, collecting the cut pieces of comb in a bamboo basket (Khara). The Kurumbas and the Irulas, on the other hand used bamboo pipes or empty gourds as receptacles (Zvelebil, 1979) while Jenu Kuruba tribe use basket lined with leaves (Demps et al., 2012), similar to the khara used by the Pnar community in Barak Valley, Assam.

The honey harvesting in the forest is a risky job, and therefore it is a group activity: three people in Kurummba (Zvelebil, 1979), 3-8 are the most common in Jenu Kuruba (Demps et al., 2012) and 5-10 people in Mowal community (Sohela, 2013) form the group. The division of labour is practiced among the group members. The Mowal community of Bangladesh adopts a technique similar to that of the Pnar community in the present study wherein they too locate a beehive by following the bee (Sohela, 2013). We did not see any rituals being performed by the Pnar community before or during honey harvesting; however, the Kurumba and Irula collectors perform certain rituals one week before the collection (Zvelebil, 1979). Women are forbidden to touch anything used in honey-gathering operations. The old generation of Jenu Kuruba tribe sings a honey collecting song (Demps et al., 2012). They also use a bamboo ladder, but the Jinkein used by the Pnar communityis very different; it is made up of a single bamboo, with steps made in it by inserting small bamboos into the long bamboo pole.

The Pnar people restrict the collection of honey only to the spring season of the year which coincides with the availability of flowers everywhere and the honey production is also recorded high during that period. Jenu Kuruba tribe from Karnataka are found to collect honey during June (Demps et al., 2012). Thus, by collecting the money during this time they ensure that they do not disturb the process as they can 
start to build fresh hives quickly after getting dislodged from the present one. Moreover, the practice of not destroying the hive completely and leaving some portion of it after honey collection to help the bees rebuild the hives once more also signifies the sustainable approach followed the communities. The community should be encouraged to take honey bee cultivation in a large way to reap more benefits out of apiculture.

Given the vital links to the basic survival and culture of many rural communities, the sustainable management of NTFPs are widely considered to be a good twinning strategy to biodiversity conservation. Sustainable management and value chain development of NTFPs can provide holistic contributions, particularly better income for rural forest resource-dependent communities, biodiversity conservation and capturing market niches for the local communities. The potential of NTFPs has not been fully realized and harnessed in the area, either for the development of the forest or for the betterment of the community. Extensive research on honey as a product is needed, to evaluate the feasibility of insitu cultivation of NTFP in the area so that maximum benefit could be reaped from the available resources, following the goal of sustainable development.

\section{Acknowledgements}

The authors thank the Head, Department of Ecology and Environmental Science, Assam University, Silchar for her support. Authors are grateful to the villagers of Marwacherra Part I and II, Bombaithol, Kayang, Nuncheeri, Durbin-Tilla, Kochukhal, Indranagar and Durgacherra village for sharing their knowledge and demonstration during the field survey. We also acknowl- edge the help received from Mr. Utpal Kumar Deka Jr. Scientist at Assam Agricultural University, Jorhat India for his help in identification oft he bees and sharing his knowledge on the honey bee.

\section{References}

Anonymous 2011. Management plan of Barail Wildlife Sanctuary, Cachar and Karimganj forest Division. Department of Environment and Forests, Govt. of Assam.

Champion, H.G. and S.K. Seth 1968. A revised survey of the forest types of India. Government of India Publications, New Delhi.

Cotton, C.M. 1996. Ethnobotany principles and applications. John Wiley and sons Ltd.

Dattagupta, S. and A. Gupta 2014.Traditional processing of non-timber forest products in Cachar, Assam, India. Indian J. Tradit. Know. 13(2): 427433.

Dattagupta, S., A. Gupta and M. Ghose 2010. Nontimber forest products of the Inner line Reserve forest, Cachar, Assam, India: dependency and usage pattern of forest dwellers. Assam University Journal of Science and Technology: Biological and Environmental Sciences 6: 21-27.

Dattagupta, S., A. Gupta and M. Ghose 2014. Diversity of non-timber forest products in Cachar District, Assam, India. J. For. Res. 25: 463-470. doi 10.1007/s11676-014-0477-7

Demps, K., F. Zorondo-Rodriguez, C. Garcia and V. Reyes-Garcia 2012. The selective persistence of local ecological knowledge: Honey collecting with the Jenu Kuruba in South India. Hum. Ecol. 40: 427-434.

Kaushal, K.K. and V.K. Melkani 2005. India: achieving the Millennium Development Goals through non-timber forest products. Int. For. Rev. 7: 128134.

Mahapatra, A.K., H.J. Albers and E.J.Z. Robinson 2005. The impact of NTFP sales on rural households' cash income in India's dry deciduous forest. Environ. Manag. 35: 258-265.

Nath, B., B.K. Dutta and S.B. Paul 2011. Medicinal plants used in curing major ailments by the Jaintia and Rongmai Naga tribes settled in Barak Valley. Assam Univ. J. Sci. and Tech.: Biolog. and Env. Sci. 7: 27-35.

Peters, C.M. 1989. Valuation of an Amazonian rainforest. Nature 339: 655-656. doi 10.1038/ $339655 \mathrm{a} 0$ 
Deori et al. / Our Nature (2016), 14 (1): 13-21

Rahman, A. and M.K. Deka 2008. Practical manual on apiculture. AICRP on Honeybee Research and Training Department of Entomology Assam Agricultural University, Jorhat.

Raut, N.B., B.S. Adhikari and G.S. Rawat 2012. Depletion of traditional knowledge of medicinal plants. Environ. Manag. 103: 873-874.

Samati, H. and S.S. Begum 2006. Plant indicators for agricultural seasons amongst Pnar tribe of Meghalaya. Indian J. Tradit. Know. 5(1): 57-59.

Singh, A.K. 2014. Traditional beekeeping shows great promises for endangered indigenous bee Apis cerana. Indian J. Tradit. Know. 3(3): 582588.
Sohela, M. 2013. The challenges and coping strategies of 'Mowal' the honey collectors of Sundarban, Bangladesh. Int. Res. J. Social Sci. 2: 7-11.

Tyagi, D. 2000. The Pnar of Jayantia hills: a bio demographic profile. Int. J. Anthropol. 15: 125136. doi 10.1007/BF02442053.

Upadhaya, A., S.S. Chaturvedi and B.K. Tiwari 2016. Utilization of wild Citrus by Khasi and Garo tribes of Meghalaya. Indian J. Tradit. Know. 15(1): 121-127.

Zvelebil, K.V. 1979. The Honey-gathering skills of a Nilgiri tribe. Anthropos 74: 577-581. http://www.jstor.org/stable/40460020. 